\title{
Exploring climate change adaptation practices and household food security in the Middle Eastern context: a case of small family farms in Central Bekaa, Lebanon
}

\author{
Aliaa Al Dirani ${ }^{1} \cdot$ Gumataw Kifle Abebe $^{2}$ (D) $\cdot$ Rachel A. Bahn $^{1} \cdot$ Giuliano Martiniello ${ }^{1,3} \cdot$ Isam Bashour $^{1}$
}

Received: 10 July 2020 / Accepted: 15 June 2021 / Published online: 26 June 2021

(C) Crown 2021

\begin{abstract}
Agriculture is the most natural resource-intensive and climate-sensitive sector. This study examines the perceptions and attitudes of small family farmers toward climate change and identifies adaptation strategies supporting household food security in the Middle Eastern context, Lebanon. The study uses cross-sectional, primary data of households that own small family farms in the Central Bekaa region. The results show that the majority of the households believe that climate change is occurring, has adverse impacts on livelihoods, and is attributable to human factors. They perceived an increase in temperature and a decrease in rainfall patterns over the last 20 years. In response, the households used multiple agricultural practices to adapt to climate change. Based on the Household Food Insecurity Access Scale (HFIAS) scores, only 7.5\% of the households were food secure, while $89 \%$ were mild to moderately food insecure. Generally, the households had modest access to nutritious diets. All the households used two or more environmentally sustainable agricultural practices. However, the use of multiple environmentally sustainable practices did not correlate with improved food security. This latter result may be due to the limited knowledge of the farmers about trade-offs between various climate change adaptation measures. The findings suggest the need to refocus research from the question of whether small family farmers are willing to adopt (or not) climate change adaptation practices to identifying those practices that are capable of balancing economic, social, and environmental goals in a specific context.
\end{abstract}

Keywords Food security $\cdot$ Family farms $\cdot$ Sustainability $\cdot$ Climate change adaptation strategies $\cdot$ Arid and semi-arid

\section{Introduction}

Agriculture is the most natural resource-based and climatesensitive sector; it is both a contributor to (via anthropogenic greenhouse gases) and a sector severely being threatened by climate change (Field et al., 2014; Pandey et al., 2017). High temperatures and changes in precipitation continue to alter water availability, reduce desirable crop yields, and increase the proliferation of weeds and pests (Arbuckle et al., 2013;

Gumataw Kifle Abebe

gumataw@gmail.com

1 Faculty of Agricultural and Food Sciences, American University of Beirut, P.O. Box 11-0236 Riad El Solh, Beirut 1107-2020, Lebanon

2 Department of Business and Social Science, Faculty of Agriculture, Dalhousie University, P.O. Box 550, Truro, Canada

3 Sciences Po Rabat, College of Law, and Political and Social Sciences, Université' Internationale de Rabat, Rabat, Morocco
Niles \& Mueller, 2016). With increasingly unsustainable farming practices, especially by large-scale farmers and illdefined resource use policies, fluctuations in temperature and rainfall patterns are likely to worsen in the future. This will hamper the ability of the agriculture sector to provide sufficient food for the growing global population and lead to a chain of economic stressors such as decreased farm income, increased poverty, and food insecurity levels (Arbuckle et al., 2013; Pandey et al., 2017; Zamasiya et al., 2017). Climate change presents significant global risks for developed and developing countries alike (Niles \& Mueller, 2016). It is threatening decades of agricultural development efforts, especially in developing countries, due to farmers' heavy reliance on rainfed agriculture (Niles \& Mueller, 2016; Pandey et al., 2017; Zamasiya et al., 2017). Even more vulnerable are those households in arid and semi-arid regions whose livelihoods and food security are disproportionally impacted by climatic conditions (Scoville-Simonds et al., 2020). Providing sufficient and nutritious food for the growing population in those highly climate-vulnerable areas while sustaining the 
ecosystem remains one of the most pressing questions in the development literature (Ali \& Erenstein, 2017). Scholars are calling for a better understanding of how individuals, climatevulnerable countries, could perceive and adapt to climate change (Elum et al., 2017; Li et al., 2017; Niles \& Mueller, 2016; Tambo \& Abdoulaye, 2013; Zamasiya et al., 2017). Also, perceptions and knowledge of climate change and adaption practices could vary across time, geographies, and cultural contexts and based on local resources and adaptive capacities (Sowers et al., 2011).

This study takes a micro-level perspective and focuses on small family farms. According to Tripathi and Mishra (2017), adaptation strategies at the local level are considered most critical. However, research on small family farmers' perceptions and attitudes toward climate change patterns and the impact this may have on food security has not received the attention it deserves (Altieri et al., 2012; Graeub et al., 2016), especially from the agro-environmental dimension (Marzin et al., 2017; Sourisseau, 2015). Small family farms tend to be ecological-friendly and could be a suitable alternative to enhance household food security (Sourisseau, 2015). They are considered more productive and environmentally sustainable than large farms (Altieri et al., 2012). The importance of small family farms in protecting the natural resources and environment is primarily attributed to their reliance on local resources, varieties, and indigenous knowledge (Altieri et al., 2012) and the ability to react differently to shocks and production diversification (Kahane et al., 2013). The perseverance (and efficiency) of small family farms is also attributed to the low transaction costs associated with the use of (cheap) family labor (Kostov et al., 2019). This strand of literature argues that the conventional high input intensification approach (under large-scale farming) has diminished the traditional agrobiodiversity (and its associated indigenous and local knowledge) by focusing on a few genetically uniform high yielding varieties (monoculturing). The loss of agrobiodiversity has, in turn, increased yield variability with, possibly, a decrease in average yield (Lanz et al., 2018). However, controversies remain in the empirical literature that small family farms are unproductive and incapable of addressing future food security challenges. For example, some empirical studies (e.g., van Vliet et al., 2015; Wuepper et al., 2020) found no support for the notion that small family farms are more sustainable than large farms. Ren et al. (2019), based on a comprehensive review, documented the superiority of large farms in enhancing economic, technical, and labor efficiency. Despite such debate, the United Nations has shown a renewed interest to reposition the status of family farms in global food security and sustainable development and declared 2014 the "International Year of Family Farming" and 2019-2028 the "UN Decade of Family Farming." Global efforts are underway to advance changes in thinking (e.g., through academic discussion) and action (e.g., through the design of context-specific policies) to enhance the contribution of small family farms to meet climate change and food security challenges (Collier \& Dercon, 2014).

Against this background, the study explores climate change adaptation practices and household food security in Lebanon, a Middle Eastern context. Specifically, the study examines (1) small family farmers' beliefs, perceptions, and attitudes about long-term changes in temperature and rainfall patterns; (2) climate change adaption practices; (3) household food security status; and (4) analyze the relationship between climate change adaptation practices and household food insecurity. We focused on small family farms because they play an essential role in Lebanese agriculture and are strongly tied to the country's natural, religious, and cultural heritages (Marzin et al., 2017) ${ }^{1}$. Lebanon is predicted to experience intensified heat stress and diminished precipitation levels due to climate change (Trærup \& Stephan, 2015). Although Lebanon has the highest cultivable land per capita in the Arab world (Bush, 2016), the contribution of small family farms to the national economy is poorly understood (Marzin et al., 2017). A better understanding of farmers' perceptions about climate change patterns will support policymakers to formulate and implement appropriate climate change adaptation measures. This study comes when Lebanon has just released its "National Agriculture Strategy 2020-2025" that aims to enhance food security and environmental sustainability by 2025 .

\section{Theoretical framework and literature review}

\subsection{Conceptualizing economic and environmental challenges of family farms}

In the theoretical literature, Friedmann (1978) conceptualizes family farms as a form of agrarian structure and a social unit balancing household and economic goals. Sourisseau et al. (2014) define family farms as an ideological framework for the protection of lifestyles, a normative framework for the promotion of policies, and an academic framework to foster knowledge production in which agriculture works. According to Marzin et al. (2017), family farms are a complex system that defines rules (e.g., gender roles), intergenerational relations, and the use of natural resources. They can be characterized based on the diversity of inputs (e.g., family labor, temporary, and migrant workers), assets (e.g., land, natural resources, human, social, physical, and financial capital), and livelihood strategies (farm and non-farm activities). The Food and Agriculture Organization (FAO) defines family farms as "a means of organizing agricultural, forestry, fisheries,

\footnotetext{
${ }^{1}$ In the context of this study, small family farms are defined based on farm size and refers to those farmers who own 10 dunums (or 1 ha) or less agricultural land (Marzin et al., 2017).
} 
pastoral and aquaculture production which is managed and operated by a family and predominantly reliant on family labor, including both women's and men's, [where] the family and the farm are linked, co-evolve and combine economic, environmental, social and cultural functions" (FAO Regional Office for Asia and the Pacific, 2013, p.6).

Conceptualizing family farms, especially in developing countries, is more challenging due to several competing (even pejorative) concepts (Sourisseau, 2015). For example, smallscale agriculture (defined by cultivated land areas), subsistence farming (defined by production and consumption purposes), peasant agriculture (defined by its communal roots), and petty commodity production are some of the concepts describing family farms. According to van Vliet et al. (2015), a universal definition of family farms is still lacking but argue that the available definitions generally embrace two important criteria- "family ownership of the land" and the "use of family labor." Despite such conceptual differences, there is a renewed interest in family farms to overcome climate change and food security challenges (Kesavan \& Swaminathan, 2014).

\subsection{Climate change adaptation strategies and small family farms}

A livelihood resilience and adaptive framework may help to understand farmers' perceptions, attitudes, and adaptation strategies (Adger et al., 2011). Tanner et al. (2015, p.23) define livelihood resilience as "the capacity of all people across generations to sustain and improve their livelihood opportunities and well-being despite environmental, economic, social and political disturbances." Although household food security depends on the intensity and severity of the shocks and stresses, a key factor is individuals' vulnerability and adaptive capacity to deal with disturbances. For safeguarding the already fragile food security situation, there is a need for natural and human systems to adapt to climate change (Zamasiya et al., 2017). Innovations (e.g., stress-tolerant varieties) and sustainable farm management practices are needed to produce more food under extreme conditions (Massel et al., 2021). Evidently, climate change is the main cause of increasing temperature and decreasing rainfall patterns worldwide (Meehl et al., 2007). The problem gets worse in climate-vulnerable regions. For example, a recent study by Zampieri et al. (2020) warned that Mediterranean and Middle East countries will be threatened even if the $2{ }^{\circ} \mathrm{C}$ mitigation target is met unless those countries take concrete action on climate change adaptation and mitigation strategies (Zampieri et al., 2020). Scientific evidence suggests that there is great scope for reducing the adverse impacts of climate change, mainly in the agriculture sector (Field et al., 2014; Lee et al., 2015).
Adaptation and mitigation to climate change may be achieved by implementing various sustainable practices in the production system of households (e.g., Deressa et al., 2011; Shikuku et al., 2017; Thornton \& Herrero, 2014). Crop diversification, inter-planting (mixed cropping), varying crop planting dates, planting early-maturing crop cultivars, and planting drought- or disease-resistant crops are relatively inexpensive farm and crop management practices and are more likely to be adopted by farmers (e.g., Deressa et al., 2011; Thornton \& Herrero, 2014). Soil management practices such as zero tillage, planting cover crops, application of manure and crop residues, and the use of legumes can increase the availability of nitrogen and other essential nutrients to increase yields (Kato et al., 2011). The adoption of water harvesting technologies (such as pools, dams, pits, and retaining ridges) and efficient water use techniques (or irrigation systems) are essential to address variability in rainfall patterns, particularly in areas affected by severe drought and water shortages. By conserving the soil structure and improving water availability, soil and water conservation practices can reduce erosion, preserve essential nutrients, and increase onfarm yields (Dumanski \& Peiretti, 2013). However, the benefits from soil and water management practices are often cumulative and long term and entail current period investment costs; thus, the likelihood of adoption by farmers may be low (Shikuku et al., 2017). Mixed (crop-livestock) farming is also one of the most common climate change adaptation practices, accounting for $50 \%$ of world food production and employing two-thirds of the world's population (Herrero et al., 2010). Mixed farming offers complementarity in resource use by integrating "different enterprises" on the farm-e.g., draft animal power for cultivation, manure for soil fertilization, and crop residues for livestock feed (Devendra \& Thomas, 2002) thus raising the yield and resource use efficiency of farming households (Thornton \& Herrero, 2014).

Climate change adaptation is a two-stage process (see Tripathi \& Mishra, 2017): first, individuals perceive climate change and its associated risks and then attempt to reduce the adverse effects of climate change. Sometimes individuals may not respond to adverse climate change effects (despite perceived risks) due to lack of resources, capacity, information, or beliefs ( $\mathrm{Li}$ et al., 2017). Also, farmers may not focus on sustaining the environment and focus on short-term gains (e.g., excessive use of groundwater for irrigation). Generally, farmers may base their climate change adaptation decisions on several factors, including familiarity of adaptation practices and economic, environmental, and social factors, as well as socioeconomic factors (Arbuckle et al., 2015). Thus, it is vital to understand farmers' perceptions and motivation and current practices to develop well-targeted policy responses for climate change and food security challenges. 


\subsection{Climate change adaptation strategies and food security}

Agricultural intensification (via the Green Revolution) has been recognized for increased farm production and reduced major staple crops' prices. However, it came at the expense of greater negative environmental consequences caused by genetic uniformity, crop vulnerability, land degradation, and intensive use of chemical inputs (Evenson \& Gollin, 2003). Moreover, the food crisis of 2008 and 2011 and the generalized growth of prices in major staple crops put this affirmation into question. It remains, however, a challenge to find an alternative approach that is more sustainable, resilient, and suitable for the environment (Massawe et al., 2016). There is an urgent need for environmentally sustainable agriculture practices that can help improve food security (Barbier et al., 2009). The notion of sustainability gained momentum with the adoption of the Sustainable Development Goals (SDGs) by the United Nations Member States in 2015. There have been increasing calls to consider "sustainability" either as an integral part of the food availability, access, utilization, and stability dimensions or as the fifth pillar measuring the longterm aspect of food security (Berry et al., 2015).

Both FAO and the World Bank have popularized "climatesmart agriculture" (CSA) as a unified concept of agriculture, development, and climate change (FAO, 2010). FAO (2010, p. ii) defines CSA as "agriculture that sustainably increases productivity, resilience (adaptation), reduces/removes GHGs (mitigation), and enhances achievement of national food security and development goals." According to this definition, all agricultural practices that have the potential to improve productivity or economize on the use of scarce resources are considered climate-smart (Neufeldt et al., 2013). Proponents of this approach argue that CSA is an innovative approach to promote the adaptive capacity of farming households (Lipper et al., 2014). However, critics contend that the CSA approach lacks specificity to measure the relationship between the three dimensions of CSA (i.e., climate change, agriculture, and development), only provides a technical fix to the already complex global food system (Neufeldt et al., 2013; Taylor, 2018), and allows limited room to integrate farming households' onfarm innovations (Whitfield, 2015). It is thus important to provide additional evidence on the interplay between climate change adaptation strategies and food security in different contexts.

\subsection{Study context}

Family farming is the predominant form of agriculture, accounting for $98 \%$ of all farms, $53 \%$ of agricultural land, and $53 \%$ of the world's food production (Graeub et al., 2016, p.1). The most commonly used thresholds for designating small farms are one and two hectares. There are more than 570 million small farms in the world (Lowder et al., 2016), of which $84 \%$ are smaller than 2 ha. Small family farms provide about $80 \%$ of the food supply in Asian and sub-Saharan Africa (Herrero et al., 2017). This paper presents a case study of family farms in Lebanon, which has favorable agroclimatic conditions and water resources compared to other countries in the Middle East. Lebanon was a prosperous agricultural country as late as the 1950s, exporting surplus agricultural production to neighboring countries. Historically, family farms were a major part of the Lebanese agrarian structure. Unfortunately, post-1950s, farmers' influence on policy and the political commitment to support family farms decreased; instead, attention dramatically shifted to the service sector (FAO, 2017). Yet, family farms remain a major part of the Lebanese agrarian structure. They grow a wide variety of permanent and seasonal crops, including fruit trees, olive trees, cereals, vegetable crops, and vines (FAO, 2017; Marzin et al., 2017). Livestock is also practiced by about $9 \%$ of the households. Most households are engaged in pluriactivity. In Lebanon, small family farms are defined as farmers that own 10 dunums ( 1 ha) or less. They account for one-fifth of the total utilized agricultural area, $70 \%$ of total farms, $53 \%$ of permanent crops, $46 \%$ of greenhouse crops, and $16 \%$ of seasonal crops (FAO, 2017). The agriculture sector, however, continued to be less attractive for the younger generation (Whitfield, 2015). For example, only $11 \%$ of Lebanese farmers are under the age of 35 , while $23 \%$ of farmers are aged over 65 (FAO, 2017). Besides the inequality of landholding and lack of political commitment, family farms in Lebanon continued to depend on imported inputs, ignoring the different ways of utilizing locally available resources and knowledge. Yet, the agriculture sector remains resilient and employs about $14 \%$ of the total workforce.

The empirical study was carried out in the Bekaa Valley, which has a continental Mediterranean climate with annual precipitation of 500 to $800 \mathrm{~mm}$. Bekaa is made up of three districts: Zahle, Western Bekaa, and Rashaya. Since ancient times, the Bekaa Valley has been a dominant agricultural region, referred to as Coele-Syria (Hollow Syria) by Alexander the Great and known as the breadbasket of Rome during the Roman Empire. The Bekaa Valley is still the "breadbasket" and "agricultural heritage" of Lebanon. However, over the last several decades, the contribution of agriculture to household income and food security has significantly decreased, primarily due to changes in temperature and rainfall patterns, water scarcity, and increasing population (Jaafar \& Ahmad, 2020). Central Bekaa was selected for the study due to several considerations. First, Bekaa Valley is the backbone of the Lebanese agriculture sector and the most productive of all the governorates. Second, compared to other governorates, farming households in the Central Bekaa practice a wide variety of farming (livestock and crop production) and non-farm activities, drawing on the work of family labor and seasonal 
workers (mainly refugees). Third, farm and non-farm activities of the households are intrinsically linked to many agroindustries located in Central Bekaa; thus, they would have to compete for scarce resources such as water and agricultural land.

\section{Materials and methods}

\subsection{Sampling and data collection}

The study was cross-sectional and adopted a quantitative approach for data collection. The selection of participants was made in two stages. In the first stage, nine villages were purposely selected to ensure socioeconomic diversity. In the second stage, the households were chosen randomly (systematic random sampling) from a list obtained from each municipality. The study only focused on small family farmers as they tend to be more vulnerable to food insecurity. A total of 120 respondents participated in the survey from the nine villages: Rayak (20), Qsarnaba (20), Khraibeh (20), Chmastar (10), Hosh el Rafika (10), Temnin el fawka (10), Nabi Cheit (10), Niha Bekaa (10), and Bednayel (10). Data were collected via face-to-face interviews using structured questionnaires approved by the Institutional Review Board at the American University of Beirut. The structured questionnaires were developed in English and then translated into the local Lebanese Arabic dialect. The questionnaires were pre-tested and necessary modifications were made accordingly.

Two sets of questionnaires were used per household —one related to climate change adaptation strategies and the other to food security. The surveys were administered in person by a research team member to 120 households; this accounted for roughly $29 \%$ of the households in the study area. The first questionnaire included socio-demographic characteristics, farmers' knowledge, perceptions, and attitudes of climate change and adaptation strategies and was administered to the head of the household. The study adopted several indicators of climate change adaptation measures in previous studies (Arbuckle et al., 2015; Masud et al., 2017; Tambo \& Abdoulaye, 2013).

The second questionnaire included information about the food security status of the household. Food security has evolved from food availability to include other dimensions such as food access and food utilization. The various aspects of food security are inherently hierarchical: food availability is a prerequisite to guarantee food access, and food access, in turn, is a necessary condition for effective utilization (Barrett, 2010). Food availability refers to having enough and appropriate quality food for consumption through domestic production, distribution, imports, exchange, and/or food aid (Webb \& Rogers, 2003). Food access relates to the ability of the households or individuals to secure adequate resources/ entitlements through purchasing, producing, or from any other source (e.g., transfer, gifts). Although sufficient food supply might be available, this does not ensure accessibility as food access might be constrained by physical or financial barriers. The food utilization dimension combines food safety and quality issues (i.e., clean water, sanitation, and health care), including adequate dietary intake of nutrients. In 2009, FAO added the food stability dimension to its definition of food security to address inherent food insecurity risks affecting the other pillars of food security such as sudden shocks (e.g., economic or climatic crisis) and cyclical events (e.g., seasonal food insecurity) (Clay, 2002). Several types of proxy measures are available to estimate food security at national, regional, community, household, and/or individual levels (Barrett, 2010). Three indexes were adopted to collect data (Coates et al., 2007): Household Food Insecurity and Access Scale (HFIAS), Months of Inadequate Household Food Provisioning (MIAHFP), and Food Consumption Score (FCS). The HFIAS index was developed based on a set of nine questions to measure the household's ability to access food and yield information on food insecurity at the household level in the previous 4 weeks. The measurement scale begins with questions about food supply anxiety, insufficiency of food quality and quantity, and ends with questions about the most severe form of food insecurity such as "going to sleep at night hungry" and "going all day and night without eating."

The questionnaire was administered to the person in charge of food preparation (nearly women, $97 \%$ ), and the person in charge was asked whether any of the household member(s) experienced any of the food insecurity situations in the previous 4 weeks, assuming three meals in a day, and, if so, the frequency of occurrence. The HFIAS scores range from 0 (food secure) to 27 (maximum level of food insecurity). The standard questionnaire consisted of nine occurrence questions (with "yes" or "no" options) and frequency of occurrence questions- "0" ("never"), "1" (rarely, 1 or 2 times), "2" (sometimes, 3 to 10 times), and " 3 " ("often," more than 10 times) during the previous month (Coates et al., 2007). The HFIAS scores are used to group the households into four food insecurity categories: food secure, mildly, moderately, and severely food insecure. The MIAHFP is used to apprehend the stability of food access in the last 12 months (through household production, purchase, or aid). Respondents were asked whether the household had enough food to meet family needs in the past 12 months and, if not, to indicate the months in which the household did not have enough food to meet the family needs. The MIAHFP score (i.e., the number of months in which the household had adequate food provisions) is the difference between the previous 12 months and the total number of months (out of the previous 12 months) that the household was unable to meet the family food needs. Data about FCS were gathered based on standardized survey questions developed by the World Food Programme (WFP) (WFP, 
2008). FCS is a composite score based on dietary diversity, food frequency, and the weighted nutritional importance of different food groups. The person in charge of food preparation was presented the nine food groups and asked to indicate the different food groups consumed by a household in the past 7 days (as "never," "hardly at all," "once in a while," or "pretty often").

\subsection{Statistical analysis}

Data were entered on Microsoft Excel 2016 and imported into STATA software (version 15.0) for both descriptive and econometric analysis. The descriptive analysis provides information on the households' sociodemographic characteristics, climate change beliefs, and changes over the past 20 years.

The Severity Index (SI) was used to measure smallholder farmers' perceptions and attitudes of climate change vulnerability. Accordingly, respondents were presented with many statements to indicate their perceptions on a 5-point Likert scale: (1) strongly disagree, (2) disagree, (3) indifferent, (4) agree, and (5) strongly agree. SI was calculated as follows (Masud et al., 2017): $S I=\left(\frac{\sum_{i=0}^{4} a_{i} n_{i}}{\sum_{i=0}^{4} n_{i}}\right)(100 \%)$

where $a_{i}$ is a constant indicating the index of a class; $n_{i}$ is a variable indicating the frequency of response (i.e., $i=0,1,2,3$, 4). Also, a0 $a_{1}, a_{2}, \mathrm{a}_{3}$, and $a_{4}$ correspond to the response frequency of $n_{0}=0, n_{1}=1, n_{2}=2, n_{3}=3$, and $n_{4}=4$. This provides the following valuation arrangement (Masud et al., 2017):

\begin{tabular}{lll}
\hline $\mathrm{q}_{0}$ & Strongly disagree & $0.00 \leq \mathrm{SI}<12.5$ \\
\hline $\mathrm{q}_{1}$ & Disagree & $12.5 \leq \mathrm{SI}<37.5$ \\
$\mathrm{q}_{2}$ & Moderate & $37.5 \leq \mathrm{SI}<62.5$ \\
$\mathrm{q}_{3}$ & Agree & $62.5 \leq \mathrm{SI}<87.5$ \\
$\mathrm{q}_{4}$ & Strongly agree & $87.5 \leq \mathrm{SI} \leq 100$ \\
\hline
\end{tabular}

To analyze the relationship between sustainable agricultural practices and household food insecurity status, we focused on the HFIAS scores. The HFIAS index provides the most relevant information about the household's food insecurity. Given the nature of the outcome variables - the number of climate change adaptation measurements - a count data model is appropriate to analyze such a relationship. The HFIAS index takes a discrete value ranging from 0 to 27 . The most common count data model in the empirical literature is the Poisson regression; it assumes that the values of the dependent variable (i.e., number of sustainable adaptation strategies adopted by a smallholder farmer) are drawn from a Poisson distribution.

\section{Results}

\subsection{Descriptive analysis}

The majority of the households (79\%) were male-headed, with an average size of five people. The mean age of the head of the household was 49 years (50 for male heads, 47 for female heads). Most household heads ( $85 \%$ ) had middle school to a higher level of education. The average size of landholding was about 8.4 dunums $(0.84$ ha). Approximately $83 \%$ of the households had access to irrigation, and $70 \%$ were engaged in farm and off-farm activities. The households spent most of their income $(54 \%)$ on food (Table 1).

Several of the socioeconomic variables in the descriptive analysis (Table 1) may aggravate the impacts of climate change on household food insecurity, especially farm and household size. With a 0.84 -ha farmland and a family size of five people, any climate shocks and stressors could easily worsen the households' food insecurity in the study context. Although most households were engaged in off-farm activities, the unprecedented economic and political unrest in Lebanon and the decreasing value of its local currency could further deteriorate the food insecurity situation of the households.

\subsection{Small family farmers' beliefs, perceptions, and attitudes about climate change}

Study participants believed that climate change is occurring and caused by human activities (48\%) or by a combination of natural changes in the environment and human activities (37\%) such as bush burning, deforestation, and pollution. In terms of changes in rainfall and temperature patterns over the past 20 years, the overwhelming majority perceived an increase in temperature and a decrease in precipitation, rainfall frequency, and length of the rainfall seasons. We also calculated SI values to analyze smallholder farmers' perceptions and attitudes of climate change vulnerability. The SI values consistently fall in the "agree" (i.e., $62.5 \leq \mathrm{SI}<87.5$ ) and "strongly agree" (i.e., $87.5 \leq \mathrm{SI} \leq 100$ ) ranges (Table 2). This suggests that smallholder farmers in the region better understand climate change vulnerability and recognize that climate change is a serious problem affecting family farms in Lebanon.

A comparative historical climatological data could be helpful to match farmers' perceptions of changes in temperature and rainfall patterns during the previous 20 years. For this purpose, we compared small farmers' perceptions with the climate data provided by NASA POWER (NASA POWER, 2021). As shown in Fig. 1a, the linear trend line showed a slight increase in the mean annual temperature (1981 to 2018), somewhat confirming the farmers' perceptions. On the other hand, the trend line related to the mean annual 
Table 1 Data and description of variables $(n=120)$

\begin{tabular}{|c|c|c|}
\hline Variable & Definition & Mean \\
\hline Gender & Household head: $1=$ male; $0=$ female & 0.79 \\
\hline Age & Household head, in years & 49.38 \\
\hline Education & Household head: $0=$ illiterate; $2=$ primary $3=$ middle school; $4=$ high school or above & 3.22 \\
\hline Family size & & 5.08 \\
\hline Farming experience & Categorical (years): $1,<=15 ; 2,16-24 ; 3,>=25$ & 2.12 \\
\hline Distance output market & In kilometers & 13.6 \\
\hline Distance input market & In kilometers & 204 \\
\hline Food expenditure & L.L., monthly ${ }^{\mathrm{a}}$ & 585,416 \\
\hline Nonfood expenditure & L.L., monthly & 497,208 \\
\hline Credit access & Binary: $1=y e s ; 0=$ no & 0.52 \\
\hline Farming households engaged in off-farm activities & Binary: $1=y e s ; 0=$ no & 0.70 \\
\hline Off-farm income & As a percentage of total income & 74.33 \\
\hline Land size & Dunum (Dn) & 8.40 \\
\hline Small family farm (\%) & Binary: $1=$ if land size $<10$ Dn; $0=$ land size $10-20 \mathrm{Dn}$ ) & 0.60 \\
\hline Irrigation access & Binary: $1=y e s ; 0=$ no & 0.83 \\
\hline
\end{tabular}

Source: Analysis of household survey data. ${ }^{\text {a }} 1 \$$ US $~ 1,508$ L.L. at the time of this study

precipitation (mm) showed no difference; this means that small farmers' perception might primarily be driven by increasing water demand for agriculture and domestic use as the population continues to rise.

\subsection{Climate change adaption practices}

The households were asked about their current agricultural practices to adapt to climate change (Fig. 2). Small farmers in the study area apply several practices such as mixed cropping, soil conservation techniques, crop rotation, chemical fertilizers, growing different varieties on the same plot, water conservation techniques, organic fertilizers, early maturing varieties, integrating trees into farming systems, crop tolerant varieties, and crop-livestock integration. The most frequently applied practices were mixed cropping, soil conservation techniques, crop rotation, chemical fertilizers, growing different varieties on the same plot (intercropping), and

Table 2 Farmers' perception and attitudes of climate change vulnerability

\begin{tabular}{|c|c|c|c|c|c|c|c|}
\hline Statement & & $\mathrm{SD}(0)$ & $\mathrm{D}(1)$ & $\mathrm{I}(2)$ & $\mathrm{A}(3)$ & $\mathrm{SA}(4)$ & $\mathrm{SI}(\%)$ \\
\hline \multirow[t]{2}{*}{ Climate change is happening } & $\mathrm{N}$ & 1 & - & 3 & 51 & 65 & \multirow[t]{2}{*}{87.29} \\
\hline & $\%$ & 0.83 & - & 2.5 & 42.5 & 54.17 & \\
\hline \multirow[t]{2}{*}{ I am concerned about the potential impacts of climate change on Bekaa's agriculture } & $\mathrm{N}$ & 4 & 1 & 10 & 44 & 61 & \multirow[t]{2}{*}{82.71} \\
\hline & $\%$ & 3.33 & 0.83 & 8.33 & 36.67 & 50.83 & \\
\hline \multirow[t]{2}{*}{ I am concerned about the potential impacts of climate change on my farm operation (i.e., production). } & $\mathrm{N}$ & - & - & 8 & 53 & 59 & \multirow[t]{2}{*}{85.63} \\
\hline & $\%$ & & & 6.67 & 44.17 & 49.17 & \\
\hline \multirow[t]{2}{*}{ I believe that extreme weather events will happen more frequently in the future } & $\mathrm{N}$ & - & 5 & 20 & 60 & 35 & \multirow[t]{2}{*}{76.04} \\
\hline & $\%$ & & 4.17 & 16.67 & 50.00 & 29.17 & \\
\hline \multirow[t]{2}{*}{ Climate change is not a big issue because human ingenuity will enable us to adapt to changes } & $\mathrm{N}$ & 5 & 13 & 23 & 60 & 19 & \multirow[t]{2}{*}{65.63} \\
\hline & $\%$ & 5 & 2 & 8 & 62 & 43 & \\
\hline \multirow[t]{2}{*}{ Bekaa farmers should take additional steps to protect their land } & $\mathrm{N}$ & 5 & 2 & 8 & 62 & 43 & \multirow[t]{2}{*}{78.33} \\
\hline & $\%$ & & & & & & \\
\hline \multirow{2}{*}{$\begin{array}{l}\text { The government should do more to reduce the nation's greenhouse gas emissions and other potential causes of } \\
\text { climate change (Mitigation) }\end{array}$} & $\mathrm{N}$ & - & - & 1 & 65 & 54 & \multirow[t]{2}{*}{86.04} \\
\hline & $\%$ & - & - & 0.83 & 54.17 & 45.00 & \\
\hline \multirow[t]{2}{*}{ I feel adaptation has become necessary for all of us. } & $\mathrm{N}$ & 4 & 2 & 8 & 50 & 56 & \multirow[t]{2}{*}{81.66} \\
\hline & $\%$ & 3.33 & 1.67 & 6.67 & 41.67 & 46.67 & \\
\hline \multirow[t]{2}{*}{ We should work together to adapt to climate change. } & $\mathrm{N}$ & - & 4 & 8 & 62 & 46 & \multirow[t]{2}{*}{81.25} \\
\hline & $\%$ & - & 3.33 & 6.67 & 51.67 & 38.33 & \\
\hline \multirow[t]{2}{*}{ I feel personally obliged to help reduce the impact of climate change in Lebanon } & $\mathrm{N}$ & 1 & 6 & 18 & 56 & 39 & \multirow[t]{2}{*}{76.25} \\
\hline & $\%$ & 0.83 & 5 & 15 & 46.67 & 32.5 & \\
\hline
\end{tabular}

Notes: N, SD, D, I, A, and SA indicate the number of respondents, "strongly disagree," "disagree," "indifferent," "agree," and "strongly agree." Source: Author's calculation based on household survey data 
Fig. 1 a Average annual temperatures $\left({ }^{\circ} \mathrm{C}\right)$ of the Bekaa Valley (at $2 \mathrm{~m}$ ) from NASA POWER data (1981-2018) (https://power.larc.nasa.gov/). b Average annual precipitation $(\mathrm{mm})$ of the Bekaa Valley from NASA POWER data (19812017) (https://power.larc.nasa. gov/)

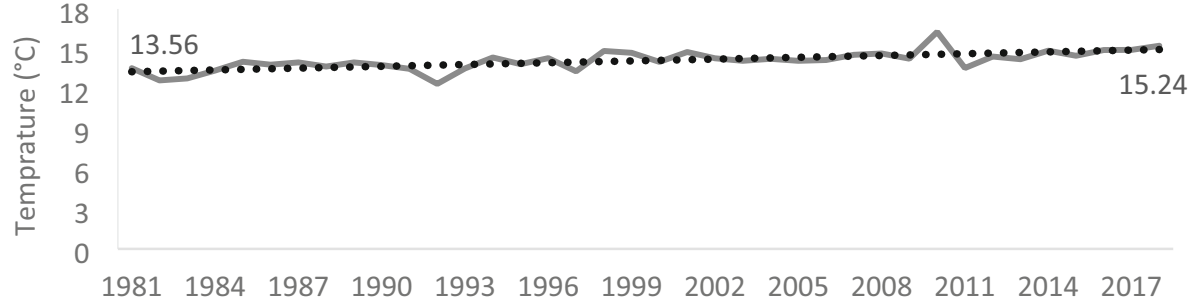

(a)

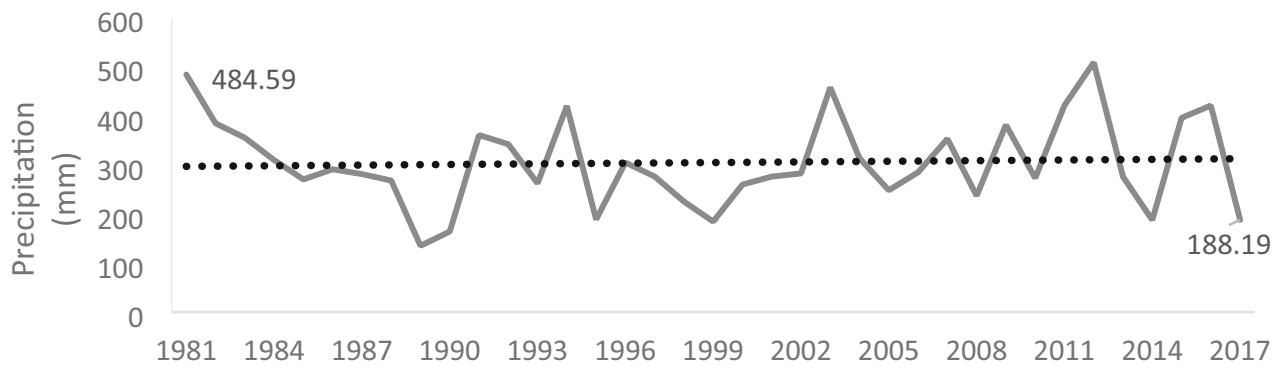

(b) application of water conservation practices, in that order. In fact, except for the use of chemical fertilizers, the other practices can be classified as sustainable, eco-friendly.

\subsection{Household food security status}

After identifying currently applied climate change adaptation strategies, it is important to explore the food security status of the households in Central Bekaa. Accordingly, the majority of the households experienced the two food insecurity domains - i.e., insufficient food quality (83\%) and anxiety and uncertainty $(75 \%)$. Only $8 \%$ of households reported the most severe food insecurity forms, which are insufficient food intake and its physical consequences. In the study context, meat, dairy products, and fruits are less accessible for poor households, forcing them to consume high-energy foods such as bread and cereals that are low quality such as essential micronutrients (Ghattas et al., 2014; Jomaa et al., 2017).

Table 3 presents HFIAS results, further disaggregating household food insecurity access-related conditions. Among those households that reported anxiety and uncertainty about food supply, most of the households experienced the condition once or twice $(54.4 \%)$ or between three to ten times $(42.2 \%)$ in the past 4 weeks. Among those households that reported insufficient food quality, coping strategies included eating non-preferred kinds of food $(90.8 \%)$, limiting the variety of food $(73.3 \%)$, and eating non-preferred food $(85.8 \%)$. Among the households that experienced insufficient food in the past 4 weeks, coping strategies included eating smaller meals $(9.2 \%)$ or eating fewer meals $(7.5 \%)$. None of the households reported the most severe coping strategies (a total lack of food, going to sleep at night hungry, or going the
Fig. 2 Agricultural practices being implemented by farming households in Central Bekaa. Source: Author's calculation based on household survey data

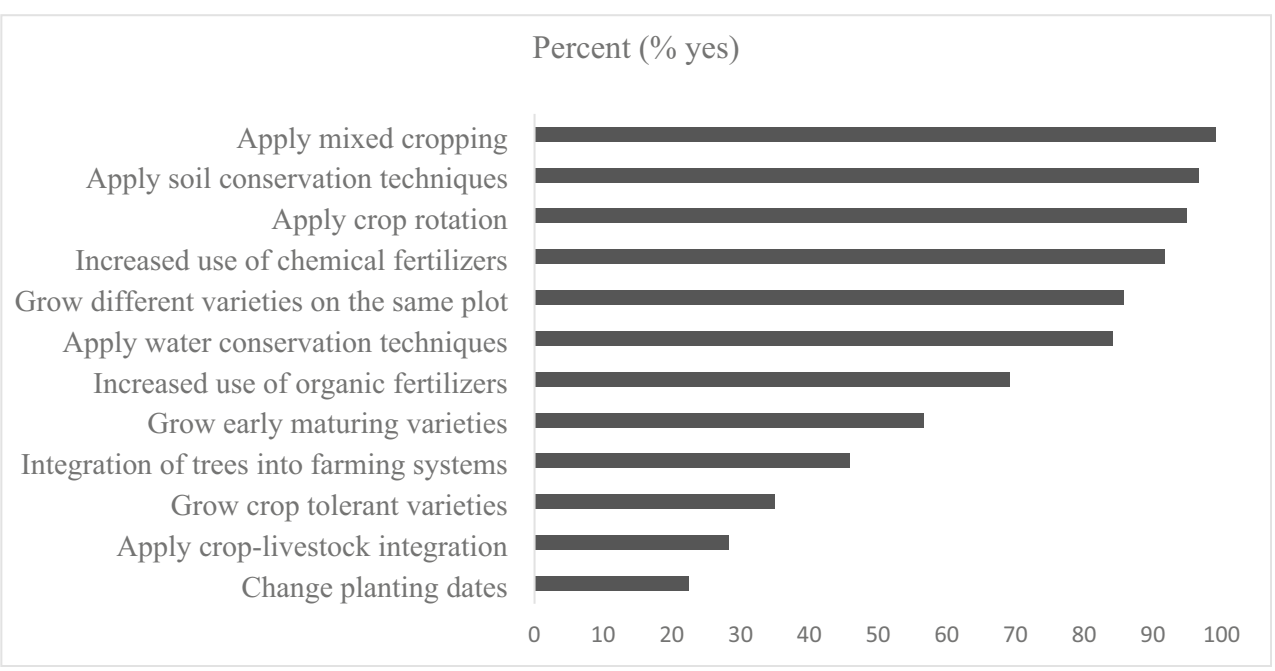


Table 3 Household food insecurity access-related conditions

\begin{tabular}{|c|c|c|c|c|c|c|c|c|}
\hline \multirow[t]{3}{*}{ Household food insecurity access-related conditions } & \multicolumn{4}{|l|}{ Occurrence } & \multicolumn{4}{|c|}{$\begin{array}{l}\text { Frequency of experience of food } \\
\text { insecurity condition in the past } 4 \text { weeks } \\
(\%)\end{array}$} \\
\hline & \multicolumn{2}{|l|}{ Yes } & \multicolumn{2}{|l|}{ No } & \multirow{2}{*}{$\begin{array}{l}\text { Once or } \\
\text { twice }\end{array}$} & \multirow{2}{*}{$\begin{array}{l}3-10 \\
\text { times }\end{array}$} & \multirow{2}{*}{$\begin{array}{l}>10 \\
\text { times }\end{array}$} & \multirow[t]{2}{*}{ Total } \\
\hline & Frequency & $\%$ & Frequency & $\%$ & & & & \\
\hline Anxiety and uncertainty about food supply & 90 & 75 & 30 & 25 & 54.44 & 42.22 & 3.33 & 100 \\
\hline \multicolumn{9}{|c|}{ Poor quality food consumption coping strategies } \\
\hline Non-preferred kinds of food ${ }^{a}$ & 109 & 90.83 & 11 & 9.17 & 60.55 & 33.03 & 6.42 & 100 \\
\hline Limited variety of food & 88 & 73.33 & 32 & 26.67 & 53.41 & 44.32 & 2.27 & 100 \\
\hline Non-preferred food ${ }^{\mathrm{b}}$ & 103 & 85.83 & 17 & 14.17 & 46.6 & 46.6 & 6.8 & 100 \\
\hline \multicolumn{9}{|l|}{ Inadequate quantity of food coping strategies } \\
\hline Ate a smaller meal than they needed & 11 & 9.17 & 109 & 90.83 & 9.09 & 63.64 & 27.27 & 100 \\
\hline Ate fewer meals in a day & 9 & 7.5 & 111 & 92.5 & 55.56 & 22.2 & 22.2 & 100 \\
\hline Experienced a total lack of food due to lack of resources & - & - & 120 & 100 & - & - & - & - \\
\hline Went to sleep at night hungry due to a lack of food & - & - & 120 & 100 & - & - & - & - \\
\hline $\begin{array}{l}\text { Going the whole day and night without eating anything due to lack } \\
\text { of food }\end{array}$ & - & - & 120 & 100 & - & - & - & - \\
\hline
\end{tabular}

Source: Author's calculation based on household survey data

${ }^{\text {a }}$ A household member was unable to eat the kinds of foods s/he preferred because of a lack of resources

${ }^{\mathrm{b}}$ A household member ate foods that s/he really did not want to eat because of a lack of resources

whole day and night without eating anything due to lack of food).

Fig. 3 shows HFIAS cores and the number of households (frequency) corresponding to those scores. The HFIAS scores range from 0 to 27 , with a higher score which implies more food insecurity in the household. As shown in Fig. 3, the median HFIAS value is 4 . The distribution of the sampled farming households, based on the HFIAS score, revealed that only $7.5 \%$ of the households were food secure (i.e., HFIAS $=0$ ). Approximately $89 \%$ of the households were mild to moderately food insecure; only $3.3 \%$ of the households were classified as severely food insecure.

The second indicator of food sufficiency is MIAHFP, which provides an indication of households' access to food and information on the months in which households had food access during the year. About $95 \%$ of the households reported that they struggled to feed household members adequately over at least five months of the previous year. February and March were the hunger months, with the highest number of food-insecure households. During those 2 months, the overwhelming majority of the sampled households stated that they did not have enough food to meet the family needs (Fig. 4).

The FCS represents the average number of food groups a household consumes in a week and hence measures relative access to a quality diet. There are nine main food groups: cereals, roots, and tubers; legumes/pulses/nuts; milk and dairy products; vegetables and leaves; fruits; meat/poultry, eggs, and fish; oil/fats/butter; sugar/sweet; and condiments/spices
(Fig. 5). According to the FCS results, the food groups with the highest rate of consumption per week were sugar/sweets, oil/fat/butter, and condiments/spices, followed by cereals, grains, roots, and tubers, vegetables and leaves, legumes and nuts, and fruits. About half of the respondents consume meat, poultry, fish, and eggs, on average, from three to six times per week. According to FCS thresholds proposed by WFG-FAO (WFP, 2008), i.e., poor (FCS $=1.0$ to 28 ), borderline (FCS = 28.1 to 42 ), and acceptable (FCS $=>42.0$ ), the FCS of all farming households in the study fell in the "acceptable" category.

The households used various coping strategies when they are unable to access enough food. The most frequently used coping strategies were purchasing food on credit, relying on less expensive or less preferred food, and consumption of seed stock held for the next season (Fig. 6). Other strategies adopted by the respondents included borrowing food, rationing money and buy prepared food, selling household possessions, selling productive goods/assets, and using savings, and avoiding health care or education costs to buy food.

\subsection{Sustainable agricultural practices and household vulnerability to food insecurity}

Finally, we analyzed the interplay between the top-ranked (Fig. 2) sustainable agricultural practices and household food insecurity status. Unsurprisingly, the households applied at least one or more sustainable agricultural practices. As shown 
Fig. 3 The degree of household food insecurity (access) in the past 4 weeks

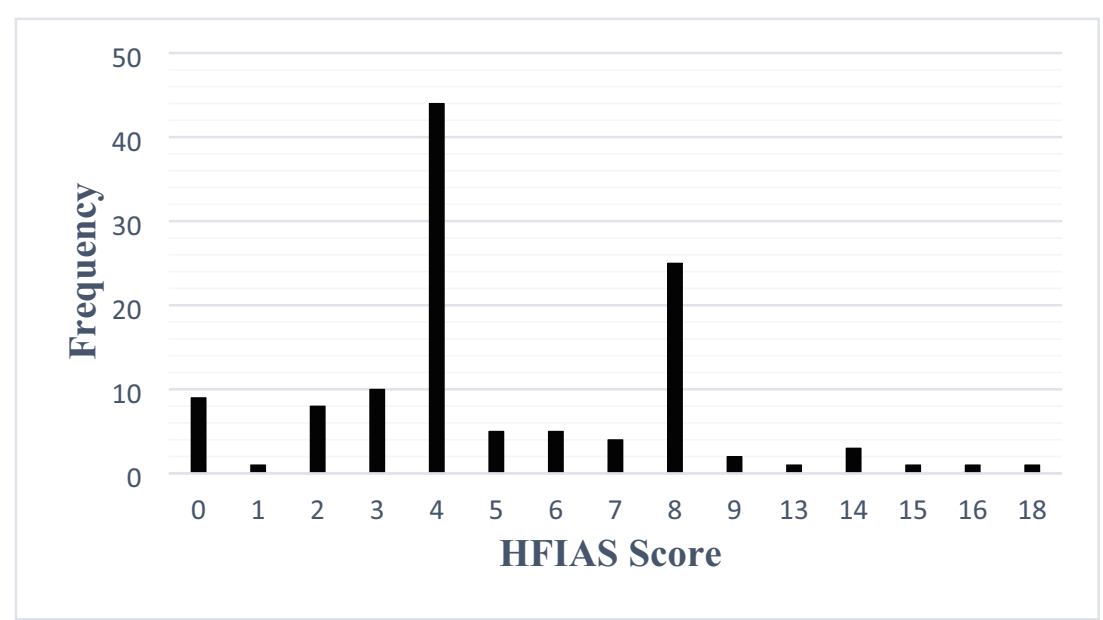

in Table 4, there is no significant difference between maleand female-headed households in terms of vulnerability to food insecurity. This finding is unexpected; nonetheless, women have always a significant role in Lebanese agriculture and participate in the labor force without much cultural and societal restriction (FAO, 2017). A study in Bangladesh also reported a similar finding (Mallick \& Rafi, 2010). Food insecurity is more likely to occur in households whose livelihoods rely more on off-farm activities. Also, food insecurity is negatively correlated with the farming experience of the household head, larger agricultural landholdings, and cropping patterns (those who mainly grow seasonal crops, vegetables, and staple crops). Most importantly, the main variable, "multipleuse of sustainable agricultural practices," is positively and strongly correlated with household food insecurity measures. This is not expected, but it could be attributed to at least two factors. First, our study is cross-sectional and thus does not capture the (potential) benefits of multiple uses of sustainable practices in the long term. Secondly, this study focused on small family farms, and implementing sustainable management practices and simultaneously addressing food security concerns may be infeasible (Cui et al., 2018).

Fig. 7 also shows the relationship between food insecurity and environmentally sustainable agricultural practices in the study area. Accordingly, those households who adopted more environmentally sustainable agricultural practices did have an increased level of food insecurity than those households that applied fewer practices.

\section{Discussion}

This study sought to explore small family farmers' attitudes and perceptions about long-term changes in temperature and rainfall patterns and vulnerability to food insecurity and analyze the relationship between the intensity of climate change adaptation practices and household food insecurity. The main findings are discussed below.
Fig. 4 Percentage of households experiencing hunger over a year. Source: Author's calculation based on household survey data

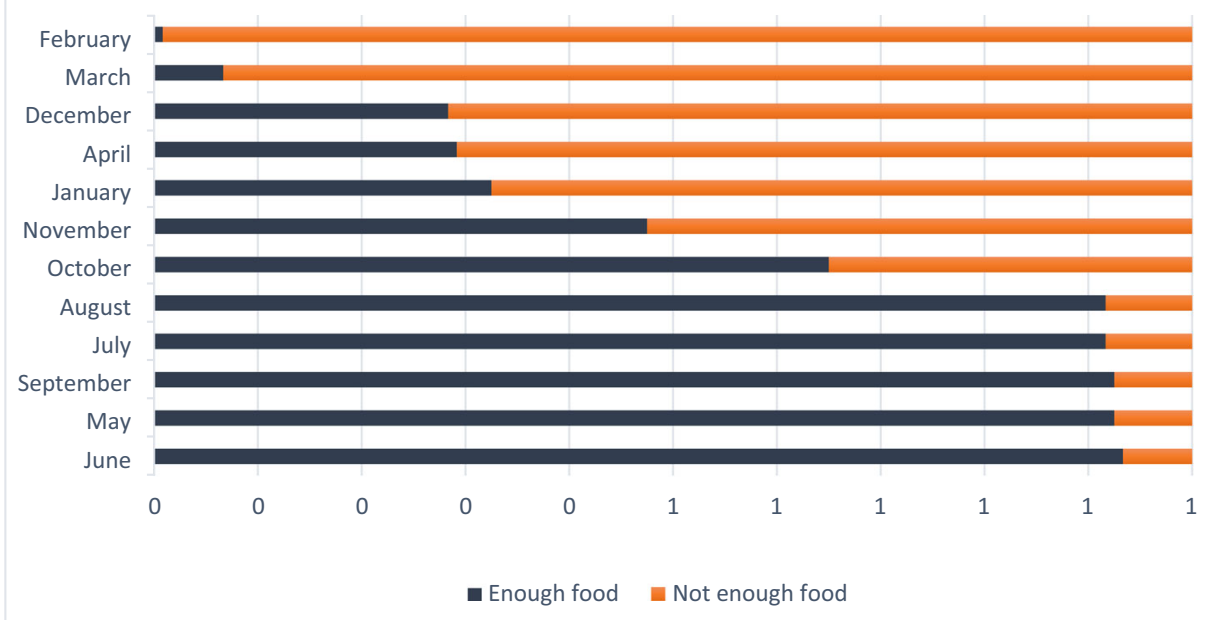

Enough food Not enough food 
Fig. 5 Food groups consumed by a household in the past week (percentage of households).

Source: Author's calculation based on household survey data

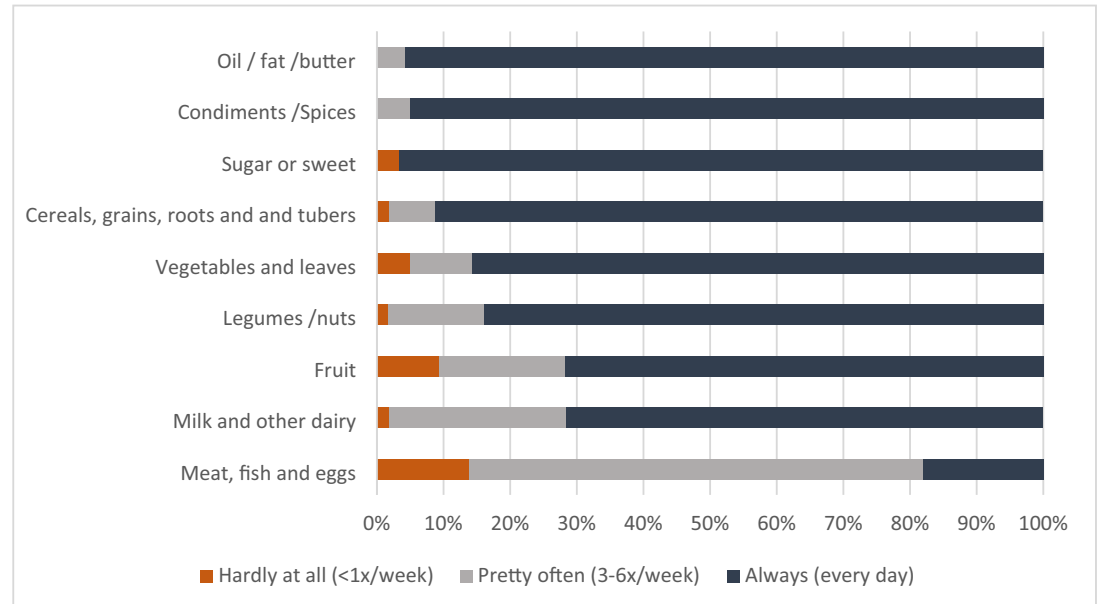

\subsection{Small family farms climate change adaption practices in central Bekaa}

The majority of the households in Central Bekaa believe that climate change is occurring, is attributed to human factors, and has adverse impacts on livelihoods. They have a great deal of understanding about the causes of climate change, which had led them to adopt various adaptation and mitigation measures. Crop-based adaptation strategies, such as mixed cropping, crop rotation, and intercropping, are among the most commonly used adaptation measures; such practices are often associated with risk reductions (Elum et al., 2017; Gebrehiwot \& Van Der Veen, 2013; Shikuku et al., 2017; Shisanya \& Mafongoya, 2016; Tripathi \& Mishra, 2017). Crop-based adaptation practices may help the households in
Central Bekaa to mitigate the risk of crop failure due to the recurring variability in rainfall patterns. Farmers in the region appeared to be more reliant on seasonal crops that require shorter growing periods (e.g., vegetables and cereals). Intensive use of chemical fertilizers and soil and water conservation techniques were the other top-ranked measures taken by the farming households in Central Bekaa. The intensive use of chemical fertilizers was expected, as the households were almost exclusively reliant on agrochemical companies for input supply and extension services. Therefore, private companies may have an incentive to push this solution, while public extension services might not be inclined to do so. Also, despite its potential to contribute to climate change mitigation and adaptation (Mbow et al., 2014) and the claim by the majority of the households that deforestation is the main cause of
Fig. 6 Percentage of farming households who occasionally or always use various coping strategies. Source: Author's calculation based on household survey data

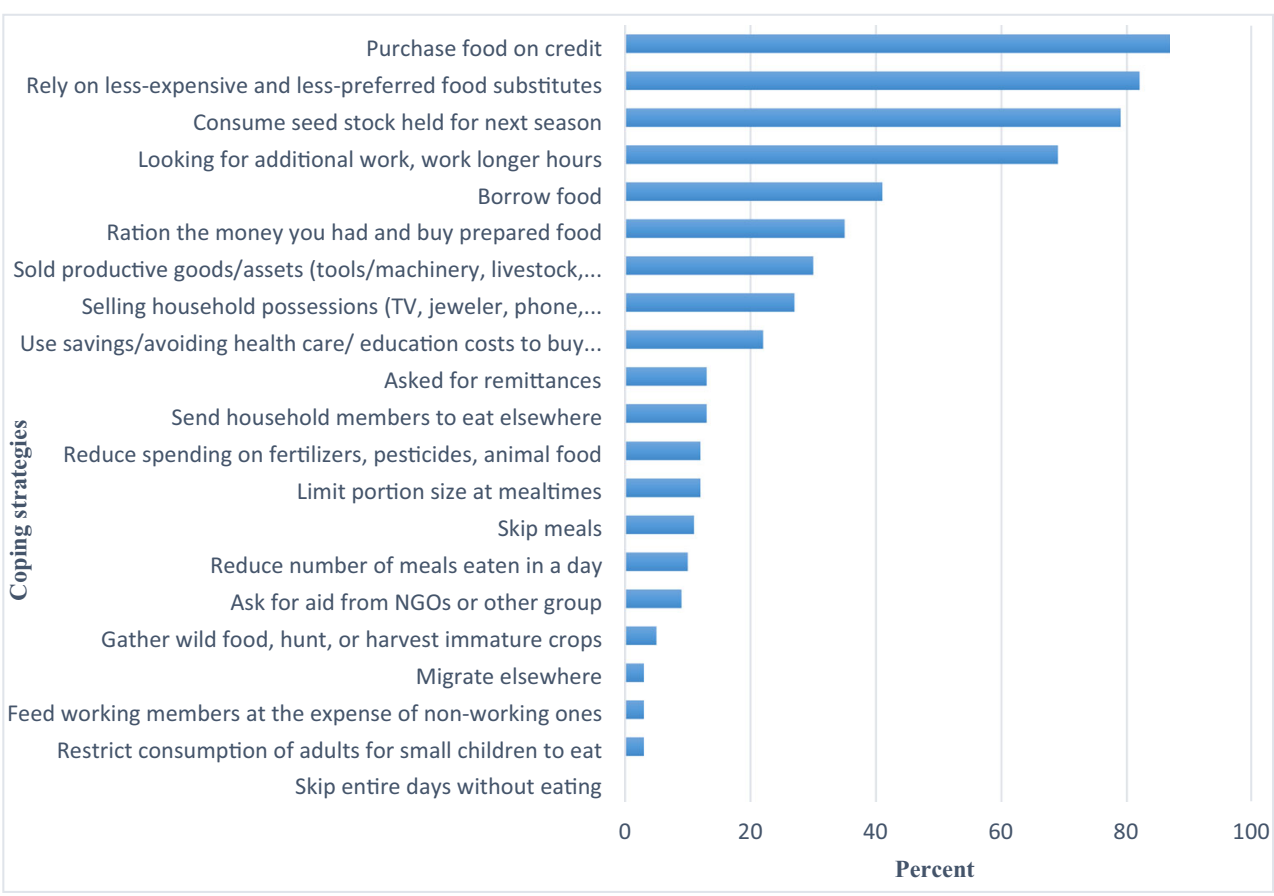


Table 4 The relationship between food insecurity and climate change adaptation practices

\begin{tabular}{ll}
\hline Variable & HFIAS (std. error) \\
\hline Demographic factors & \\
Gender & $0.072(0.107)$ \\
Age & $0.008(0.005)$ \\
Education $(1=$ none; $4=$ high school and above) & $0.011(0.062)$ \\
Household size & $0.074^{* * *}(0.029)$ \\
Farming experience & $-0.125^{*}(0.067)$ \\
Family farm type $(1=$ small, $0=$ medium) & $0.296^{* * *}(0.092)$ \\
Off-farm income $(\%$ of total family income) & $0.004^{* * *}(0.002)$ \\
Farming characteristics & \\
Livestock (\# cattle: $0=\leq 5 ; 1=>5)$ & $0.005(0.124)$ \\
Seasonal crops & \\
Vegetables (focused $1=$ yes; $0=$ no) & $-0.176^{* * *}(0.041)$ \\
Cereal crops (focused $1=$ yes; $0=$ no) & $-0.225^{* *}(0.097)$ \\
Permanent crops (focused $1=$ yes; $0=$ no) & $0.132(0.093)$ \\
Multiple-use of sustainable agriculture practices & $0.168^{* *}(0.072)$ \\
Constant & $-0.114(0.504)$ \\
Pse R-squared & 0.0982 \\
Prob $>$ chi2 & 0.0000 \\
\hline
\end{tabular}

$* P$-value $<0.10 ; * * P$-value $<0.05 ; * * * P$-value $<0.01$.

climate change, agroforestry is relatively not among the topranked adaptation measures in the study context. Institutional support may be needed to raise awareness about the economic, social, and environmental benefits of agroforestry (see for example Pandey et al., 2017).

The households use multiple environmentally sustainable agricultural practices. This is consistent with a study in Oman (Choudri et al., 2013) but in contrast to the findings in subSaharan Africa in which higher percentages of non-adopters have been reported (Fosu-Mensah et al., 2012; Tambo \& Abdoulaye, 2013; Zamasiya et al., 2017). We suggest two explanations. First, countries in semi-arid and arid regions have severe water scarcity, making sustainable agricultural practices critical to adapt to the adverse effects of climate change on agriculture (Ragab \& Prudhomme, 2002). The Middle East is the most water-stressed region in the world (Joffe, 2016). Due to increasing temperatures and decreasing rainfall patterns, most farmers in Central Bekaa use irrigated agriculture $(82.5 \%)$. In the previous 5 years alone, groundwater levels have decreased by more than $15 \mathrm{~m}$ (see, for example, Jaafar \& Ahmad, 2020). Thus, the households in this study are increasingly concerned about the depletion of groundwater sources. The use of multiple adaptation strategies in Central Bekaa may suggest the households' response to counter the effect of climate change on agriculture. Second, Bekaa Valley has been a focus of research by many local and regional institutions such as the Lebanese Agricultural Research Institute (LARI), the International Center for Agricultural Research in the Dry Areas (ICARDA), and the American University of Beirut (AUB). For example, AUB has been testing the ecological and yield impacts of conservation agriculture in the Bekaa valley (Chalak et al., 2017). Such interventions should have raised awareness of the importance of environmentally sustainable agriculture practices.

\subsection{Household food security in central Bekaa}

Overall, the results of the food security questionnaire revealed that most households had insufficient food security scores. Based on HFIAS, only $7.5 \%$ of the households were fully food secure, and around 3\% of them were fully food insecure. The remaining $89 \%$ were mild to moderately food insecure. The level of food insecurity in the study area is higher than that of Jomaa et al. (2019), based on nationally representative data. This suggests the vulnerability of those households relying on agriculture. FCS, which captures food quality and diversity, based on food groups consumed over the past seven days, indicates acceptable nutrition among the households. Also, the MIAHFP index showed February and March being the hunger months. Food purchase was the principal coping mechanism for the households in the study. This is not surprising as pluriactivity is one of the main features of family farms; the overwhelming majority (70\%) of the households
Fig. 7 Relationship between food insecurity and environmentally sustainable agricultural practices in Central Bekaa

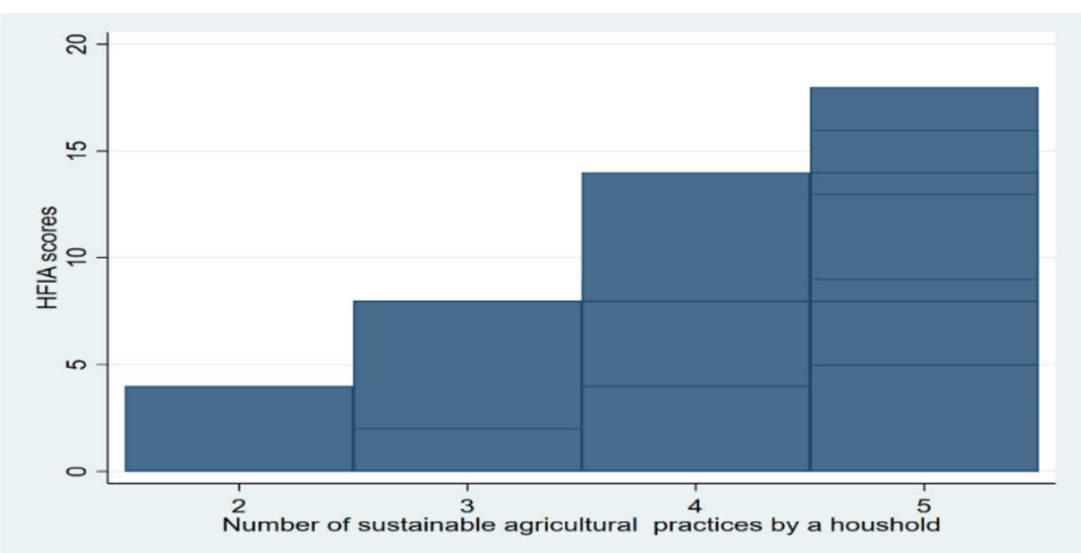


combine agricultural and non-agricultural activities for their livelihoods. The question remains, however, on the implication of increasing off-farm income activities on the future of agriculture and household food security. Although off-farm activity may help households to overcome short-term liquidity problems (including the purchase of agricultural inputs), it can negatively affect agricultural production (Pfeiffer et al., 2009). Generally, the households may engage in non-farm income activities temporarily, as an intermediate means to expand or quit farming, or strategically as part of their lifestyle (to combine rural life) and permanent job off the farm to increase family income (Blad, 2010). In fact, given the significance of small family farms in Lebanon's natural, religious, and cultural heritages, pluriactivity appears to be a key aspect of the agrarian structure. However, if public policy continues to ignore the agriculture sector, some farmers may exit the sector and use their farms to generate non-agricultural income permanently.

Lebanon is heavily reliant on food imports (about $80 \%$ of total food demand) and has inherent food insecurity risks. The country was already in an economic meltdown before the recent global pandemic (COVID-19) started; the economic crisis led to the eruption of public protest on 17 October 2019. The combined effects of the economic crisis and COVID-19 have led the value of the Lebanese Lira to fall by more than $80 \%$ against the US dollar and deteriorated the country's food security situation.

\subsection{Relationships between sustainable agriculture practices and household food security}

One major contribution of this study is its focus on exploring the interplay between environmentally sustainable agricultural practices and household food security. Of the currently applied 12 agricultural practices, 11 of them were environmentally sustainable, and all the households used two or more of such practices. We focused on the top five environmentally sustainable practices for the correlation analysis-i.e., mixed cropping, soil conservation, crop rotation, intercropping, and water conservation. These practices were implemented by more than $80 \%$ of the households. For household food insecurity, we used the HFIAS scores.

Scholars, international organizations, national governments, and civic societies have been increasingly calling for sustainable practices that can simultaneously address food security goals. Some studies have also found a positive relationship between the adoption of multiple adaptation practices and higher food security levels (e.g., Ali \& Erenstein, 2017). However, a study in Malawi found no significant relationship between the number of sustainable practices and household income (Maguza-Tembo et al., 2017). This may be attributed to competing social, economic, and ecological goals while implementing different environmentally sustainable practices (Miller et al., 2011). For example, trade-offs could arise when individual farmers have competing uses of farmland (Klapwijk et al., 2014); this may become more difficult when such tradeoffs involve small family farmers, such as in the study context, whose land size is on average 0.84 ha. Those households who adopted more environmentally sustainable agricultural practices did have an increased level of food insecurity. Small family farmers are likely to have many competing challenges regarding environmental sustainability and food security goals. Further analysis of the various adaptation practices that were implemented by the households revealed evidence of complementarity and trade-offs (see Appendix). Unfortunately, government institutions have little support to improve the households' adaptive capacity to deal with potential trade-offs. CSA has been promoted as a useful approach to mitigate climate change challenges, identify synergies and trade-offs on agriculture, and propose context-specific climate change adaptation solutions (Lipper et al., 2014). However, CSA has been criticized for its lack of specificity on the relationship between climate change, agriculture, and development (Neufeldt et al., 2013; Taylor, 2018) and its failure to incorporate local innovations (Whitfield, 2015). Unfortunately, in Lebanon, agriculture extension service is left largely to the private sector (agrochemical companies). Although private extension may be useful to promote the uptake of new agricultural technologies, agrochemical companies operate under a business model that may not always align with sustainability objectives. A public extension can help build small family farmers' capacity to select appropriate sustainable practices balancing climate change adaptation and food security goals.

Looking at the other socioeconomic variables, those households whose large portion of the family income comes from off-farm activities tend to have increased food insecurity levels. Although off-farm activities could contribute to household food security, the findings in the study suggest otherwise. We provide the following explanations. Lebanon is heavily reliant on food imports. Furthermore, due to the political and economic uncertainties, the value of the Lebanese Lira continues to fall against the US dollar, further deteriorating the country's food security situation. Therefore, those households who rely more on off-farm activities than agriculture are likely to be heavily dependent on markets to access most of the household food demand, disproportionately affecting their food security situation. Also, households who focused on seasonal crops such as vegetables and staples (e.g., cereals, tuber crops) were more likely to have improved food security than those with permanent crops. This is not surprising because seasonal crops are often the primary targets for agricultural 
intensification. Households can easily maximize crop yields by using high agricultural inputs and alter their production decision depending on market conditions. The availability of low-wage labor (due to the refugees) in the area may be another incentive to focus on intensive agriculture and seasonal crops. Also, the market price for vegetables may be increasing due to behavioral changes toward healthier diets. Several studies in Africa have shown the contribution of high-value vegetable production on household incomes (e.g., Douxchamps et al., 2016). However, farmers' decision to focus on seasonal crops such as vegetables may not necessarily relate to climate change (see, e.g., Barbier et al., 2009). A slight change in temperature and rainfall patterns can have a detrimental effect on the yield and quality of vegetables (Ahmad \& Rasool, 2014). In the study context, households are increasingly reliant on irrigated agriculture to overcome fluctuations in rainfall patterns. There is already evidence of the depletion of groundwater sources in the region due to the over-pumping of water for irrigated agriculture (Jaafar \& Ahmad, 2020).

\section{Conclusions and policy implications}

The study sought to examine the perceptions and attitudes toward changes in rainfall and temperature patterns, which identify climate change adaptation strategies supporting household food security in the arid and semi-arid Middle Eastern context. The overwhelming majority of households believed that climate change is occurring and caused by human activities. More specifically, they noted a significant increase in temperature and a decrease in rainfall amount, frequency, and length of the rainy season. Despite the small farm size, all the households implemented multiple sustainable adaptation practices, and the main ones include mixed cropping, soil conservation techniques, crop rotation, intercropping, and water conservation techniques. However, we found a strong negative correlation between the use of multiple sustainable practices and food security, providing evidence of potential trade-offs in applying multiple sustainable practices. It is possible that more households that are vulnerable to food insecurity are not applying the techniques properly, for example, due to resource shortages, or they try many things but only serve to dilute efforts rather than improve resilience. The findings suggest a need to refocus research from the question of whether family farmers are willing to adopt (or not) climate change adaptation practices to identifying and creating awareness of those practices balancing social, economic, and environmental sustainability in a specific context.
By focusing on the perceptions and attitudes of small family farmers and their climate change adaptation strategies and food security, the study contribute to the debate on the future of family farms as a path to sustainable food production (Graeub et al., 2016). Such studies are scant in Lebanon and the Middle East. One study from Lebanon, Trærup and Stephan (2015), focused on the economic feasibility of (two) selected technologies to adapt to climate change-rainwater harvesting and conservation agriculture. In another study of Oman, Choudri et al. (2013) documented the adaptation strategies of farming communities in the Al-Batinah coastal region. Furthermore, available studies in the Middle Eastern context have focused on the role of large-scale projects, such as desalination plants, dams, inter-basin water transfers, groundwater aquifers, and virtual water imports, on food security (Sowers et al., 2011, p.599).

The study also provides several implications for policy in the study context. First, there is a need for clearly designed agricultural policies capitalizing on local opportunities to revive agriculture and prevent excessive switching of small family farmers to off-farm activities. The study indicates a failure in the public extension system and ambiguity on the use of multiple (environmentally sustainable) adaptation practices. The government should expand its extension services to reach out to small family farmers and build their capacity to use innovative climate change adaptation practices that can economize on the scarcer resources in the region, such as water and agricultural land. Second, revitalizing the agriculture sector should include easing liquidity constraints of small family farms and providing crop insurance mechanisms to improve their access to farm inputs, markets, and finance. Third, the country has inherent food insecurity risks, and the younger generations are increasingly less interested in agriculture. This might lead households to turn their farms into non-farm activities permanently. The households are aware of changes in temperature and rainfall patterns and attempting to adapt to such changes by using multiple practices. However, their decision needs to be supported by scientific evidence and proper training. The recent global pandemic (COVID-19) has given a harsh lesson to Lebanon that has relied on food imports by prioritizing its resources to sectors outside of agriculture. This unfortunate global pandemic is another reminder of the importance of local production and small family farms more than ever. Finally, seasonal crops (such as vegetables and cereals) are contributing to food security in the region. However, this may further exacerbate the increasing use of input-intensive agriculture and groundwater resources for irrigated agriculture in Bekaa Valley. Attention needs to be paid to alternative water sources. Studies are showing promising results on the use of recycled or treated wastewater for irrigated agriculture 
while maintaining the quality and yield of many horticultural crops in arid and semi-arid environments (Libutti et al., 2018). Soil mulching and drip irrigation are also other environmentally sustainable practices that could enhance water efficiency in production agriculture (Nouri et al., 2019). Rainwater harvesting is also found to be economically feasible in the context of Lebanon (Trærup \& Stephan, 2015).

As a final note, although the study used primary data to achieve its objectives, future research may look into some of the limitations or unexpected findings from this study. The findings suggest that the use of multiple sustainable agricultural practices may not always improve food security, especially at the level of small family farms. However, this study was cross-sectional and did not capture the long-term benefits of such practices. Future research may use panel data or crosscountry studies to explore potential trade-offs and synergies between the current and future sustainable practices. Also, the relatively small sample size (120 households) makes the generalization of the findings somehow difficult. This limitation however does not invalidate the study conclusions rather it encourages further research covering the whole of Lebanon and the region.

\section{Appendix}

Table 5 Pairwise coefficients of climate change adaptation practices in Central Bekaa

\begin{tabular}{|c|c|c|c|c|c|c|c|c|c|c|c|}
\hline Adaptation strategies & (1) & (2) & (3) & (4) & $(5)$ & (6) & (7) & (8) & (9) & $(10)$ & (11) \\
\hline \multicolumn{12}{|l|}{ Change planting dates (1) } \\
\hline Grow early maturing varieties (2) & $\begin{array}{l}0.431 \\
* * *\end{array}$ & & & & & & & & & & \\
\hline Grow different varieties on the same plot (3) & 0.104 & $\begin{array}{l}0.272 \\
* * *\end{array}$ & & & & & & & & & \\
\hline $\begin{array}{l}\text { Integration of trees into farming systems/shading } \\
\text { for animals (4) }\end{array}$ & -0.055 & $\begin{array}{l}0.399 \\
* * *\end{array}$ & $\begin{array}{c}0.182 \\
* *\end{array}$ & & & & & & & & \\
\hline Apply soil conservation techniques (5) & -0.122 & 0.025 & $\begin{array}{c}0.191 \\
* *\end{array}$ & -0.016 & & & & & & & \\
\hline Apply water conservation Techniques (6) & $\begin{array}{l}0.234 \\
* * *\end{array}$ & $\begin{array}{l}0.450 \\
* * *\end{array}$ & $\begin{array}{r}0.544 \\
* * *\end{array}$ & $\begin{array}{l}0.307 \\
* * *\end{array}$ & -0.081 & & & & & & \\
\hline Apply mixed cropping (7) & 0.049 & 0.105 & $\begin{array}{c}0.226 \\
* *\end{array}$ & 0.084 & $\begin{array}{r}0.494 \\
* * *\end{array}$ & -0.040 & & & & & \\
\hline Apply crop rotation (8) & $\begin{array}{c}-0.151 \\
*\end{array}$ & 0.108 & 0.016 & -0.019 & $\begin{array}{l}0.383 \\
* * *\end{array}$ & -0.100 & -0.021 & & & & \\
\hline Grow drought tolerant varieties (9) & 0.149 & -0.099 & 0.098 & 0.096 & -0.058 & 0.223 & -0.125 & 0.008 & & & \\
\hline Apply crop-livestock integration (10) & 0.148 & -0.047 & $\begin{array}{c}-0.275 \\
* * *\end{array}$ & $\begin{array}{c}-0.207 \\
* *\end{array}$ & 0.117 & $\begin{array}{c}-0.183 \\
* *\end{array}$ & 0.058 & 0.059 & 0.004 & & \\
\hline Increased use of chemical fertilizers (11) & $\begin{array}{c}-0.245 \\
* * *\end{array}$ & 0.144 & 0.143 & $\begin{array}{l}0.361 \\
* * *\end{array}$ & -0.024 & $\begin{array}{r}0.452 \\
* * *\end{array}$ & -0.061 & 0.095 & 0.149 & $\begin{array}{c}-0.221 \\
* *\end{array}$ & \\
\hline Increased use of organic fertilizers (12) & -0.054 & 0.101 & $\begin{array}{l}0.310 \\
* * *\end{array}$ & 0.035 & $\begin{array}{l}0.448 \\
* * *\end{array}$ & 0.034 & $\begin{array}{l}0.304 \\
* * *\end{array}$ & 0.346 & -0.095 & $\begin{array}{c}-0.212 \\
* *\end{array}$ & 0.19 \\
\hline
\end{tabular}

$* P$-value $<0.10 ; * * P$-value $<0.05 ; * * * P$-value $<0.01$ 


\section{Declarations}

Conflict of interest The authors declare no competing interests.

\section{References}

Adger, W. N., Brown, K., Nelson, D. R., Berkes, F., Eakin, H., Folke, C., et al. (2011). Resilience implications of policy responses to climate change. Wiley Interdisciplinary Reviews: Climate Change, 2(5), 757-766.

Ahmad, P., \& Rasool, S. (2014). Emerging technologies and management of crop stress tolerance: Volume 2-A sustainable approach: Academic Press.

Ali, A., \& Erenstein, O. (2017). Assessing farmer use of climate change adaptation practices and impacts on food security and poverty in Pakistan. Climate Risk Management, 16, 183-194.

Altieri, M. A., Funes-Monzote, F. R., \& Petersen, P. (2012). Agroecologically efficient agricultural systems for smallholder farmers: Contributions to food sovereignty. Agronomy for Sustainable Development, 32(1), 1-13.

Arbuckle, J. G., Prokopy, L. S., Haigh, T., Hobbs, J., Knoot, T., Knutson, C., et al. (2013). Climate change beliefs, concerns, and attitudes toward adaptation and mitigation among farmers in the Midwestern United States. Climatic Change, 117(4), 943-950.

Arbuckle, J. G., Morton, L. W., \& Hobbs, J. (2015). Understanding farmer perspectives on climate change adaptation and mitigation: The roles of trust in sources of climate information, climate change beliefs, and perceived risk. Environment and Behavior, 47(2), 205 234

Barbier, B., Yacouba, H., Karambiri, H., Zoromé, M., \& Somé, B. (2009). Human vulnerability to climate variability in the Sahel: Farmers' adaptation strategies in northern Burkina Faso. Environmental Management, 43(5), 790-803.

Barrett, C. B. (2010). Measuring food insecurity. Science, 327(5967), $825-828$.

Berry, E. M., Dernini, S., Burlingame, B., Meybeck, A., \& Conforti, P. (2015). Food security and sustainability: Can one exist without the other? Public Health Nutrition, 18(13), 2293-2302.

Blad, M. (2010). Pluriactivity of farming families-old phenomenon in new times. Rural Areas and. Development, 7(740-2016-50932), $155-165$.

Bush, R. (2016). Family farming in the Near East and North Africa. No. 151. Working Paper Working Paper.

Chalak, A., Irani, A., Chaaban, J., Bashour, I., Seyfert, K., Smoot, K., \& Abebe, G. K. (2017). Farmers' Willingness to adopt conservation agriculture: New evidence from Lebanon. Environmental Management, 60(4), 693-704.

Choudri, B. S., Al-Busaidi, A., \& Ahmed, M. (2013). Climate change, vulnerability and adaptation experiences of farmers in Al-Suwayq Wilayat, Sultanate of Oman. International Journal of Climate Change Strategies and Management.

Clay, E. (2002). Food security: concepts and measurement, paper for FAO expert consultation on trade and food security: Conceptualising the linkages Rome, FAO.

Coates, J., Swindale, A., \& Bilinsky, P. (2007). Household Food Insecurity Access Scale (HFIAS) for measurement of food access: Indicator guide (v.2). Washington, DC: Food and Nutrition Technical Assistance Project, Academy for Educational Development.

Collier, P., \& Dercon, S. (2014). African agriculture in 50 years: Smallholders in a rapidly changing world? World Development, 63, 92-101.
Cui, Z., Zhang, H., Chen, X., Zhang, C., Ma, W., Huang, C., Zhang, W., Mi, G., Miao, Y., Li, X., Gao, Q., Yang, J., Wang, Z., Ye, Y., Guo, S., Lu, J., Huang, J., Lv, S., Sun, Y., Liu, Y., Peng, X., Ren, J., Li, S., Deng, X., Shi, X., Zhang, Q., Yang, Z., Tang, L., Wei, C., Jia, L., Zhang, J., He, M., Tong, Y., Tang, Q., Zhong, X., Liu, Z., Cao, N., Kou, C., Ying, H., Yin, Y., Jiao, X., Zhang, Q., Fan, M., Jiang, R., Zhang, F., \& Dou, Z. (2018). Pursuing sustainable productivity with millions of smallholder farmers. Nature, 555(7696), 363-366.

Deressa, T. T., Hassan, R. M., \& Ringler, C. (2011). Perception of and adaptation to climate change by farmers in the Nile basin of Ethiopia. The Journal of Agricultural Science, 149(1), 23-31.

Devendra, C., \& Thomas, D. (2002). Crop-animal interactions in mixed farming systems in Asia. Agricultural Systems, 71(1-2), 27-40.

Douxchamps, S., Van Wijk, M. T., Silvestri, S., Moussa, A. S., Quiros, C., Ndour, N. Y. B., et al. (2016). Linking agricultural adaptation strategies, food security and vulnerability: Evidence from West Africa. Regional Environmental Change, 16(5), 1305-1317.

Dumanski, J., \& Peiretti, R. (2013). Modern concepts of soil conservation. International soil and water conservation research, 1(1), 1923.

Elum, Z. A., Modise, D. M., \& Marr, A. (2017). Farmer's perception of climate change and responsive strategies in three selected provinces of South Africa. Climate Risk Management, 16, 246-257.

Evenson, R. E., \& Gollin, D. (2003). Assessing the impact of the Green Revolution, 1960 to 2000. science, 300(5620), 758-762.

FAO. (2010). Food and Agriculture Organization of the United Nations: "Climate-Smart" Agriculture: Policies, Practices and Financing for Food Security. Adaptation and Mitigation.

FAO. (2017). Study of small-scale family farming in the Near East and North Africa: Focus country: Lebanon [Étude sur l'agriculture familiale a petite échelle au proche-orient et afrique du nord pays focus Liban]. FAO, CIHEAM-IAMM, and CIRAD Retrieved from http://www.fao.org/3/a-i6608f.pdf.

FAO Regional Office for Asia and the Pacific (2013). Outcome report of the regional dialogue on family farming: Sustainable rural development and food security, 21-22 November 2013.

Field, C. B., Barros, V. R., Mastrandrea, M. D., Mach, K. J., Abdrabo, M.-K., Adger, N., et al. (2014). Summary for policymakers. In Climate change 2014: impacts, adaptation, and vulnerability. Part A: global and sectoral aspects. Contribution of Working Group II to the Fifth Assessment Report of the Intergovernmental Panel on Climate Change (pp. 1-32): Cambridge University Press.

Fosu-Mensah, B. Y., Vlek, P. L., \& MacCarthy, D. S. (2012). Farmers' perception and adaptation to climate change: A case study of Sekyedumase district in Ghana. Environment, Development and Sustainability, 14(4), 495-505.

Friedmann, H. (1978). Simple commodity production and wage labour in the American plains. The Journal of Peasant Studies, 6(1), 71-100.

Gebrehiwot, T., \& Van Der Veen, A. (2013). Farm level adaptation to climate change: The case of farmer's in the Ethiopian Highlands. Environmental Management, 52(1), 29-44.

Ghattas, H., Sassine, A. J., Seyfert, K., Nord, M., \& Sahyoun, N. R. (2014). Food insecurity among Iraqi refugees living in Lebanon, 10 years after the invasion of Iraq: Data from a household survey. British Journal of Nutrition, 112(1), 70-79.

Graeub, B. E., Chappell, M. J., Wittman, H., Ledermann, S., Kerr, R. B., \& Gemmill-Herren, B. (2016). The state of family farms in the world. World Development, 87, 1-15. https://doi.org/10.1016/j. worlddev.2015.05.012.

Herrero, M., Thornton, P. K., Notenbaert, A. M., Wood, S., Msangi, S., Freeman, H., et al. (2010). Smart investments in sustainable food production: Revisiting mixed crop-livestock systems. Science, 327(5967), 822-825.

Herrero, M., Thornton, P. K., Power, B., Bogard, J. R., Remans, R., Fritz, S., Gerber, J. S., Nelson, G., See, L., Waha, K., Watson, R. A., West, P. C., Samberg, L. H., van de Steeg, J., Stephenson, E., van Wijk, 
M., \& Havlík, P. (2017). Farming and the geography of nutrient production for human use: A transdisciplinary analysis. The Lancet Planetary Health, 1(1), e33-e42.

Jaafar, H. H., \& Ahmad, F. A. (2020). Time series trends of Landsatbased ET using automated calibration in METRIC and SEBAL: The Bekaa Valley, Lebanon. Remote Sensing of Environment, 238, 111034.

Joffe, G. (2016). The Impending Water Crisis in the MENA Region. The International Spectator, 51(3), 55-66.

Jomaa, L., Naja, F., Cheaib, R., \& Hwalla, N. (2017). Household food insecurity is associated with a higher burden of obesity and risk of dietary inadequacies among mothers in Beirut, Lebanon. BMC Public Health, 17(1), 1-14.

Jomaa, L., Naja, F., Kharroubi, S., \& Hwalla, N. (2019). Prevalence and correlates of food insecurity among Lebanese households with children aged 4-18 years: Findings from a national cross-sectional study. Public Health Nutrition, 22(2), 202-211.

Kahane, R., Hodgkin, T., Jaenicke, H., Hoogendoorn, C., Hermann, M., Hughes, J. d. A., et al. (2013). Agrobiodiversity for food security, health and income. Agronomy for Sustainable Development, 33(4), 671-693.

Kato, E., Ringler, C., Yesuf, M., \& Bryan, E. (2011). Soil and water conservation technologies: A buffer against production risk in the face of climate change? Insights from the Nile basin in Ethiopia. Agricultural Economics, 42(5), 593-604.

Kesavan, P., \& Swaminathan, M. (2014). 2014 International Year of Family Farming: A boost to evergreen revolution. Current Science, 1970-1974.

Klapwijk, C. J., van Wijk, M. T., Rosenstock, T. S., van Asten, P. J. A., Thornton, P. K., \& Giller, K. E. (2014). Analysis of trade-offs in agricultural systems: Current status and way forward. Current Opinion in Environmental Sustainability, 6, 110-115. https://doi. org/10.1016/j.cosust.2013.11.012.

Kostov, P., Davidova, S., \& Bailey, A. (2019). Comparative efficiency of family and corporate farms: Does family labour matter? Journal of Agricultural Economics, 70(1), 101-115. https://doi.org/10.1111/ 1477-9552.12280.

Lanz, B., Dietz, S., \& Swanson, T. (2018). The expansion of modern agriculture and global biodiversity decline: An integrated assessment. Ecological Economics, 144, 260-277.

Lee, T. M., Markowitz, E. M., Howe, P. D., Ko, C.-Y., \& Leiserowitz, A. A. (2015). Predictors of public climate change awareness and risk perception around the world. Nature Climate Change, 5(11), 10141020.

Li, S., Juhász-Horváth, L., Harrison, P. A., Pintér, L., \& Rounsevell, M. D. (2017). Relating farmer's perceptions of climate change risk to adaptation behaviour in Hungary. Journal of Environmental Management, 185, 21-30.

Libutti, A., Gatta, G., Gagliardi, A., Vergine, P., Pollice, A., Beneduce, L., Disciglio, G., \& Tarantino, E. (2018). Agro-industrial wastewater reuse for irrigation of a vegetable crop succession under Mediterranean conditions. Agricultural Water Management, 196, 1-14. https://doi.org/10.1016/j.agwat.2017.10.015.

Lipper, L., Thornton, P., Campbell, B. M., Baedeker, T., Braimoh, A., Bwalya, M., Caron, P., Cattaneo, A., Garrity, D., Henry, K., Hottle, R., Jackson, L., Jarvis, A., Kossam, F., Mann, W., McCarthy, N., Meybeck, A., Neufeldt, H., Remington, T., Sen, P. T., Sessa, R., Shula, R., Tibu, A., \& Torquebiau, E. F. (2014). Climate-smart agriculture for food security. Nature Climate Change, 4(12), 1068-1072.

Lowder, S. K., Skoet, J., \& Raney, T. (2016). The number, size, and distribution of farms, smallholder farms, and family farms worldwide. World Development, 87, 16-29.

Maguza-Tembo, F., Mangison, J., Edris, A. K., \& Kenamu, E. (2017). Determinants of adoption of multiple climate change adaptation strategies in Southern Malawi: An ordered probit analysis. Journal of Development and Agricultural Economics, 9(1), 1-7.

Mallick, D., \& Rafi, M. (2010). Are female-headed households more food insecure? Evidence from Bangladesh. World Development, 38(4), 593-605. https://doi.org/10.1016/j.worlddev.2009.11.004.

Marzin, J., Bonnet, P., Bessaoud, O., \& Ton-Nu, C. (2017). Study on small-scale family farming in the Near-East and North Africa region: synthesis. FAO.

Massawe, F., Mayes, S., \& Cheng, A. (2016). Crop diversity: An unexploited treasure trove for food security. Trends in Plant Science, 21(5), 365-368. https://doi.org/10.1016/j.tplants.2016.02.006.

Massel, K., Lam, Y., Wong, A. C., Hickey, L. T., Borrell, A. K., \& Godwin, I. D. (2021). Hotter, drier, CRISPR: The latest edit on climate change. Theoretical and Applied Genetics, 1-19.

Masud, M. M., Azam, M. N., Mohiuddin, M., Banna, H., Akhtar, R., Alam, A. S. A. F., \& Begum, H. (2017). Adaptation barriers and strategies towards climate change: Challenges in the agricultural sector. Journal of Cleaner Production, 156, 698-706. https://doi. org/10.1016/j.jclepro.2017.04.060.

Mbow, C., Smith, P., Skole, D., Duguma, L., \& Bustamante, M. (2014). Achieving mitigation and adaptation to climate change through sustainable agroforestry practices in Africa. Current Opinion in Environmental Sustainability, 6, 8-14. https://doi.org/10.1016/j. cosust.2013.09.002.

Meehl, G. A., Covey, C., Delworth, T., Latif, M., McAvaney, B., Mitchell, J. F., et al. (2007). The WCRP CMIP3 multimodel dataset: A new era in climate change research. Bulletin of the American Meteorological Society, 88(9), 1383-1394.

Miller, T. R., Minteer, B. A., \& Malan, L.-C. (2011). The new conservation debate: The view from practical ethics. Biological Conservation, 144(3), 948-957. https://doi.org/10.1016/j.biocon. 2010.04.001.

NASA POWER (2021). Climatology resource for agroclimatology (https://power.larc.nasa.gov/data-access-viewer/).

Neufeldt, H., Jahn, M., Campbell, B. M., Beddington, J. R., DeClerck, F., De Pinto, A., et al. (2013). Beyond climate-smart agriculture: Toward safe operating spaces for global food systems. Agriculture $\&$ Food Security, 2(1), 12.

Niles, M. T., \& Mueller, N. D. (2016). Farmer perceptions of climate change: Associations with observed temperature and precipitation trends, irrigation, and climate beliefs. Global Environmental Change, 39, 133-142.

Nouri, H., Stokvis, B., Galindo, A., Blatchford, M., \& Hoekstra, A. Y. (2019). Water scarcity alleviation through water footprint reduction in agriculture: The effect of soil mulching and drip irrigation. Science of the Total Environment, 653, 241-252. https://doi.org/ 10.1016/j.scitotenv.2018.10.311.

Pandey, R., Aretano, R., Gupta, A. K., Meena, D., Kumar, B., \& Alatalo, J. M. (2017). Agroecology as a climate change adaptation strategy for smallholders of Tehri-Garhwal in the Indian Himalayan region. Small-scale forestry, 16(1), 53-63.

Pfeiffer, L., López-Feldman, A., \& Taylor, J. E. (2009). Is off-farm income reforming the farm? Evidence from Mexico. Agricultural Economics, 40(2), 125-138.

Ragab, R., \& Prudhomme, C. (2002). Sw-soil and Water: climate change and water resources management in arid and semi-arid regions: Prospective and challenges for the 21 st century. Biosystems Engineering, 81(1), 3-34.

Ren, C., Liu, S., van Grinsven, H., Reis, S., Jin, S., Liu, H., \& Gu, B. (2019). The impact of farm size on agricultural sustainability. Journal of Cleaner Production, 220, 357-367. https://doi.org/10. 1016/j.jclepro.2019.02.151.

Scoville-Simonds, M., Jamali, H., \& Hufty, M. (2020). The hazards of mainstreaming: Climate change adaptation politics in three dimensions. World Development, 125, 104683. 
Shikuku, K. M., Winowiecki, L., Twyman, J., Eitzinger, A., Perez, J. G., Mwongera, C., \& Läderach, P. (2017). Smallholder farmers' attitudes and determinants of adaptation to climate risks in East Africa. Climate Risk Management, 16, 234-245.

Shisanya, S., \& Mafongoya, P. (2016). Adaptation to climate change and the impacts on household food security among rural farmers in uMzinyathi District of Kwazulu-Natal, South Africa. [journal article]. Food Security, 8(3), 597-608. https://doi.org/10.1007/s12571016-0569-7.

Sourisseau, J.-M. (2015). Family farming and the worlds to come. 10.1007/978-94-017-9358-2: Dordrecht: Springer [Pays-Bas], Ed. Quae, $371 \mathrm{p}$.

Sourisseau, J.-M., Bosc, P.-M., Freguin-Gresh, S., Bélières, J.-F., Bonnal, P., Le Coq, J.-F., et al. (2014). Diversity in family farming: Theoretical and empirical approaches to its many forms. Pretoria: University of Pretoria, 46 p. (Rethinking Development Working Paper Series). N ${ }^{\circ} 2014 / 2 .:$ University of Pretoria.

Sowers, J., Vengosh, A., \& Weinthal, E. (2011). Climate change, water resources, and the politics of adaptation in the Middle East and North Africa. Climatic Change, 104(3-4), 599-627.

Tambo, J. A., \& Abdoulaye, T. (2013). Smallholder farmers' perceptions of and adaptations to climate change in the Nigerian savanna. Regional Environmental Change, 13(2), 375-388.

Tanner, T., Lewis, D., Wrathall, D., Bronen, R., Cradock-Henry, N., Huq, S., Lawless, C., Nawrotzki, R., Prasad, V., Rahman, M. A., Alaniz, R., King, K., McNamara, K., Nadiruzzaman, M., Henly-Shepard, S., \& Thomalla, F. (2015). Livelihood resilience in the face of climate change. Nature Climate Change, 5(1), 23-26.

Taylor, M. (2018). Climate-smart agriculture: what is it good for? The Journal of Peasant Studies, 45(1), 89-107.

Thornton, P. K., \& Herrero, M. (2014). Climate change adaptation in mixed crop-Livestock systems in developing countries. Global Food Security, 3(2), 99-107. https://doi.org/10.1016/j.gfs.2014.02. 002 .
Trærup, S., \& Stephan, J. (2015). Technologies for adaptation to climate change. Examples from the agricultural and water sectors in Lebanon. Climatic Change, 131(3), 435-449.

Tripathi, A., \& Mishra, A. K. (2017). Knowledge and passive adaptation to climate change: An example from Indian farmers. Climate Risk Management, 16, 195-207.

van Vliet, J. A., Schut, A. G. T., Reidsma, P., Descheemaeker, K., Slingerland, M., van de Ven, G. W. J., \& Giller, K. E. (2015). Demystifying family farming: Features, diversity and trends across the globe. Global Food Security, 5, 11-18. https://doi.org/10.1016/j.gfs. 2015.03.001.

Webb, P., \& Rogers, B. (2003). Addressing the "in" in Food Security. USAID Office.

WFP (2008). Interagency Workshop Report WFP - FAO Measures of Food Consumption - Harmonizing Methodologies Rome, 9 - 10 April 2008.

Whitfield, S. (2015). Adapting to climate uncertainty in African agriculture: Narratives and knowledge politics: Routledge.

Wuepper, D., Wimmer, S., \& Sauer, J. (2020). Is small family farming more environmentally sustainable? Evidence from a spatial regression discontinuity design in Germany. Land Use Policy, 90, 104360. https://doi.org/10.1016/j.landusepol.2019.104360.

Zamasiya, B., Nyikahadzoi, K., \& Mukamuri, B. B. (2017). Factors influencing smallholder farmers' behavioural intention towards adaptation to climate change in transitional climatic zones: A case study of Hwedza District in Zimbabwe. Journal of Environmental Management, 198, 233-239.

Zampieri, M., Toreti, A., Ceglar, A., Naumann, G., Turco, M., \& Tebaldi, C. (2020). Climate resilience of the top ten wheat producers in the Mediterranean and the Middle East. Regional Environmental Change, 20(2). https://doi.org/10.1007/s10113-020-01622-9. 


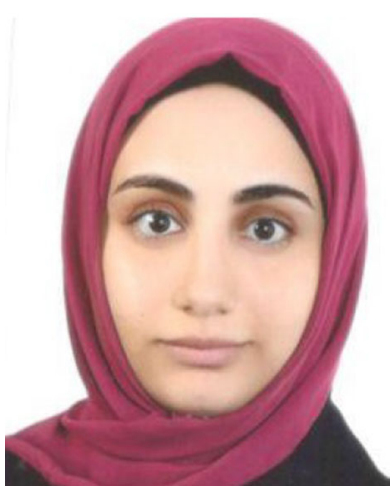

Aliaa Al Dirani is currently a doctoral student at Skema Business School, Lille-France. She holds two master's degrees - in food security and environmental sciences - and received her bachelor's degree in environmental health with a minor in public health from the American University of Beirut (AUB). Previously, she worked as a graduate research assistant at the Faculty of Agriculture and Food Sciences, American University of Beirut (FAFSAUB). Her research interests include sustainability, food security, water scarcity, climate change, and rural development. Email: aliaa.aldirani@gmail.com

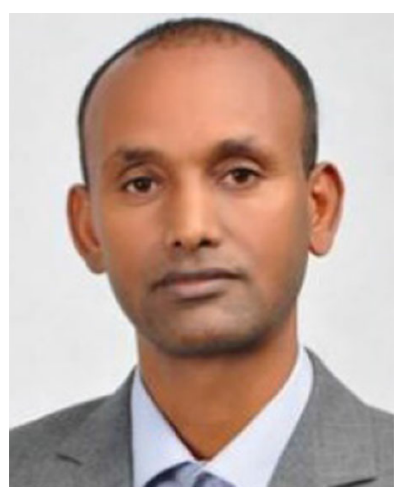

Gumataw Kifle Abebe is Assistant Professor at the Faculty of Agriculture, Dalhousie University, Canada. Dr. Abebe holds a $\mathrm{PhD}$ (in Agribusiness Management) from Wageningen University \& Research, The Netherlands, in 2013, and a Master of Business Administration from Leipzig Graduate School of Management (HHL), Germany, in 2007. His research focuses on exploring the efficiency and effectiveness of agrifood supply (value) chains in responding to food safety, food quality, and food security challenges. Email: gumataw@gmail.com

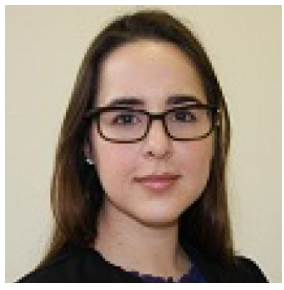

Rachel Anne Bahn is an instructor of agribusiness and the coordinator of the Food Security Program at the American University of Beirut; and a doctoral student at Montpellier SupAgro. Her research interests include food systems and food security; the intersection of agriculture and conflict; and economic policies and programming in developing county contexts. She holds an MA degree from the Johns Hopkins University School of Advanced International Studies in 2008 and a BA from Saint Joseph's University (Philadelphia, PA) in 2004. Email: rb89@aub.edu.lb

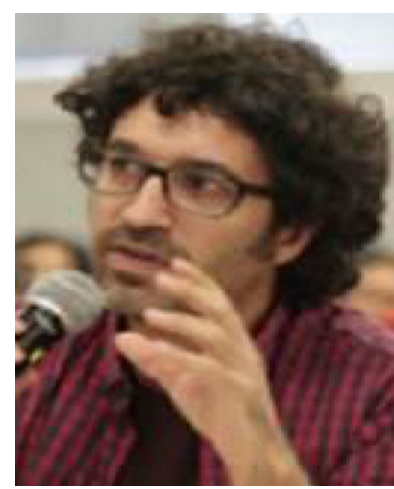

Giuliano Martiniello is Associate Professor of Political Science at Sciences Po Rabat, College of Law, and Political and Social Sciences, Université, Internationale de Rabat and Adjunct Associate Professor at the Faculty of Agricultural and Food Sciences, American University of Beirut. He holds a Ph.D. in politics and international studies and an MA in Africa: human and sustainable development, both from the University of Leeds. He is broadly interested in the political economy and political ecology of agrarian change with particular reference to land dispossession, labour and land tenure regimes, food security/sovereignty, peasant social struggles and market-based land reforms in South Africa, Uganda and Tanzania. Email:giuliano.martiniello@uir.ac.ma; gm43@aub.edu.lb

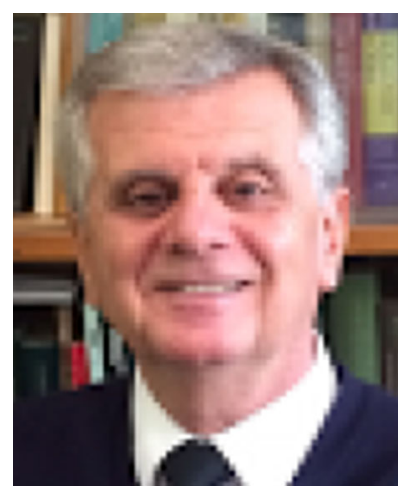

Isam Bashour is Professor of Soil Science and Plant Nutrition, and Interim Chairperson of the Department of Agriculture at the American University of Beirut Beirut (AUB), Lebanon. He obtained his $\mathrm{PhD}$ from the University of California at Davis and MSc from AUB. He worked as Assistant Professor at California State University for a year and a senior soil scientist at the Regional Agriculture and Water Research Center in Riyadh, Saudi Arabia, before joining AUB in 1998 as an Associate Professor. His research interests are in the area of soil and human health, land reclamation, and fertilizer technology and use. Email: iibashour@gmail.com 